\title{
POLITIK HUKUM TERHADAP PEDAGANG KAKI LIMA DARI PERSPEKTIF UNDANG-UNDANG DASAR NEGARA REPUBLIK INDONESIA
}

\author{
Yohanes Suhardin \\ Fakultas Hukum Universitas Katolik Santo Thomas, Medan, Indonesia \\ Email : johnsuhardin@gmail.com
}

\begin{abstract}
ABSTRAK
Eksistensi Undang-Undang Dasar Negara Republik Indonesia Tahun 1945 sejatinya telah cukup jelas melingkupi juga masyarakat marginal yang salah satunya adalah pedagang kaki lima (PKL), meskipun secara tersurat tidak dapat dibaca. Hal tersebut sudah tampak dari salah satu tujuan nasional yang terdapat dalam Alinea ke-4 Pembukaan Undang-Undang Dasar Negara Republik yang menyatakan "memajukan kesejahteraan umum". Namun secara tersirat tampak pada ketentuan Pasal 34 Undang-Undang Dasar Negara Republik Indonesia Tahun 1945 khususnya ayat (2) negara mengembangkan sistem jaminan sosial bagi seluruh rakyat dan memberdayakan masyarakat yang lemah dan tidak mampu sesuai dengan martabat kemanusiaan. Memajukan kesejahteraan (kebaikan) umum yang disebut bonum commune, maka termasuk di dalamnya masyarakat marginal khususnya para pedagang kaki lima yang secara khusus dianalisis dalam artikel ini. Dengan demikian, politik hukum terhadap pedagang kaki lima dari perspektif Undang-Undang Dasar Negara Republik Indonesia Tahun 1945 sudah memadai, dan yang harus ditingkatkan adalah kemauan politik keberpihakan terhadap pedagang kaki lima.
\end{abstract}

Kata kunci: Politik hukum, pedagang kaki lima, UUD 1945

\begin{abstract}
The existence of the 1945 Constitution of the State of the Republic of Indonesia has been quite clear that it also encompasses marginal communities, one of which is street vendors, although explicitly it cannot be read. This is already apparent from one of the national goals contained in the 4th paragraph Opening of the Constitution of the Republic of the Republic which states "promoting public welfare". However, it is implicit in the provisions of Article 34 of the 1945 Constitution of the Republic of Indonesia in particular paragraph (2) of the state developing a social security system for all people and empowering people who are weak and unable to comply with human dignity. Promote general welfare (goodness) called bonum commune, including the marginal community, especially the street vendors who are specifically analyzed in this article. Thus, legal politics towards street vendors from the perspective of the 1945 Constitution of the Republic of Indonesia is adequate, and what must be improved is the political will of partiality towards street vendors.
\end{abstract} Keywords: Political law, street vendors, 1945 Constitution. 


\section{A. PENDAHULUAN}

Pedagang kaki lima merupakan salah satu dari unsur kelompok-kelompok marginal (marginal groups) adalah kelompok masyarakat miskin dan tidak teruntungkan, ${ }^{1}$ sedangkan kelompok rentan adalah kelompok-kelompok di dalam masyarakat yang secara obyektif terdominasi akibat tatanan kemasyarakatan (ekonomi, politik dan budaya) yang tidak berpihak kepada mereka. Di antara kelompok-kelompok tersebut adalah kaum miskin secara keseluruhan, buruh, petani miskin, nelayan, pedagang kecil (pedagang kaki lima), perempuan, anakanak, masyarakat adat, dan kaum miskin perkotaan. Sebagian besar dari kelompokkelompok marginal itu sebagai informal di perkotaan terserap ke dalam sektor perdagangan yaitu pedagang jalanan atau sebagai pedagang kaki lima, yang saat ini di Indonesia berjumlah sekitar 20 juta jiwa. $^{2}$

Kota-kota besar yang tergolong metropolitan seperti Jakarta, Surabaya, Medan, Bandung dan beberapa kota besar lainnya merupakan ajang pertempuran dinamika sosial masyarakat, khususnya masyarakat kelompok-kelompok marginal seperti pedagang kaki lima, akibatnya sering terjadi konflik dalam pengaturan lingkungan. Eksistensi pedagang kaki lima menimbulkan konflik pemaknaan ruang dengan kaum formal (pengusaha) dan pemerintah Daerah. Konflik ruang tersebut disebabkan oleh pemaknaan ruang yang berbeda antara pemerintah Daerah, kaum formal dan masyarakat pada umumnya dengan kaum informal. Bagi Pemerintah Daerah pemaknaan ruang telah sesuai dengan tata ruang kota, sedangkan bagi kelompok informal, ruang itu merupakan peluang atau kesempatan untuk berjualan dan berdagang. Dalam konsep tata ruang, ada ruang khusus untuk pertokoan, perumahan, taman kota, fasilitas publik, trotoar, pasar dan lain-lain yang semuanya memberikan kenyamanan bagi warga kota. Bagi kelompok informal - pedagang kaki lima, taman kota, trotoar, pinggir jalan serta fasilitas publik lainnya merupakan peluang untuk berdagang.

${ }^{1}$ Adnan Buyung Nasution - A. Patra M. Zen (Penyunting), Instrumen Internasional PokokPokok Hak Asasi Manusia, Yayasan Obor Indonesia - Yayasan Lembaga Bantuan Hukum Indonesia - Kelompok Ake Arief, Jakarta, 2006, hlm. Xviii.

2 Dalam Musyawarah Nasional Asosiasi Pedagang Kaki Lima Indonesia (APKLI) IV yang dilaksanakan di Semarang, 12-13 Maret 2011 lalu dilaporkan Pedagang Kaki Lima di Indonesia mencapai jumlah 20 juta jiwa yang dihadiri oleh pengurus tingkat pusat dari 22 Provinsi seIndonesia, lihat Harian Umum Suara Merdeka, Semarang, 12 Maret 2011.

Politik Hukum Terhadap Pedagang Kaki Lima Dari Perspektif Undang-Undang Dasar Negara Republik Indonesia.

Oleh : Yohanes Suhardin 
Perbedaan pemaknaan tersebut menyebabkan konflik peruntukannya. Sebenarnya sudah sangat jelas bahwa pemaknaan dan peruntukan ruang kota telah memiliki landasan hukumnya, baik berdasarkan Peraturan Daerah tentang Tata Ruang yang ada pada setiap kota-kota besar di Indonesia, maupun berdasarkan Peraturan Daerah tentang Ketertiban Umum. Intinya adalah dilarang berjualan dan berdagang di tempat-tempat seperti trotoar, taman kota, badan jalan dan fasilitas publik lainnya. Selain melanggar peraturan Perundang-undangan juga menggangu ketertiban umum, keteraturan dan ketenteraman masyarakat pada umumnya, seperti para pejalan kaki, mereka kehilangan akses untuk menggunakan trotoar yang seharus merupakan hak normatif mereka.

Akibat pemaknaan yang berbeda itu, pedagang kaki lima tetap memanfaatkan ruang terbuka itu, sementara Pemerintah Daerah menganggapnya sebagai pelanggaran terhadap Peraturan Daerah khususnya tentang Ketertiban Umum. Dalam pemaknaan yang berbeda tersebut pola mengusir dan menggusur perdagangan kaki lima dari tempat-tempat sebagaimana telah disebutkan dianggap terapi yang tepat oleh kebanyakan pemerintah daerah saat ini di Indonesia dengan alasan eksistensi pedagang kaki lima yang menguasai trotoar melanggar Peraturan Daerah tentang Ketertiban Umum.

Memang akhir-akhir ini mengusir dan menggusur pedagang kaki lima diikuti dengan kebijakan berupa lokalisasi di tempat-tempat tertentu, tetapi tidak selalu menjadikan pedagang kaki lima membaik kondisi ekonominya. Tindakan mengusir dan menggusur pedagang kaki lima memiliki aspek hukum dan sekaligus politik khususnya kebijakan dari Pemerintah Daerah. Sesungguhnya, Pancasila dan Undang Undang Dasar Negara Republik Indonesia Tahun 1945 baik secara tersirat maupun tersurat telah menjadi penuntun dalam membangun sistem hukum nasional Indonesia sebagai upaya mengangkat harkat dan martabat masyarakat di Indonesia khususnya masyarakat marginal seperti masyarakat pedagang kaki lima.

\section{B. PERMASALAHAN}

Berdasarkan uraian singkat pada latar belakang tersebut di atas, maka permasalahannya adalah "Bagaimana politik hukum terhadap pedagang kaki lima dari perspektif Undang-Undang Dasar Negara Republik Indonesia Tahun 1945”? 


\section{PEMBAHASAN}

\section{Pengertian Politik Hukum dan Konstitusi}

Politik hukum menurut Bellefroid adalah bagian dari ilmu hukum yang meneliti perubahan hukum yang berlaku yang harus dilakukan untuk memenuhi tuntutan baru kehidupan masyarakat dengan menyatakan:

"De rechtspolitiek onderzoekt, welke veranderingen in het maatschappelijk leven te volden. Sij zet den ontwikkelingsgang der rechtsorde voort. Want uit het uit vroegere rechtsstelsels ontwikkelde "Jus Constitutum", trcaht zij het "Jus Constituendum" of het rechts der toekomst op te bouwen". ${ }^{3}$

Bahwasanya politik hukum menyelidiki perubahan-perubahan apakah yang harus diadakan pada hukum yang ada sekarang, supaya dapat memenuhi syaratsyarat baru dari hidup kemasyarakatan. Ia melanjutkan perkembangan tertib hukum. Karena ia mencoba menjadikan ius constitutum yang diperkembangkan dari stelsel-stelsel hukum yang lama, menjadi ius constituendum atau hukum untuk masa yang akan datang. ${ }^{4}$

Lemaire berpendapat bahwa politik hukum termasuk kajian hukum yang terkait dengan ilmu pengetahuan hukum positif (aan positive rechtswetenschap verwante rechtsstudie). Selanjutnya dikatakan, politik hukum merupakan bagian dari kebijakan legislatif. ${ }^{5}$ Politik hukum merupakan bagian dari ilmu politik pada umumnya. Politik hukum mengkaji bagaimana penetapan hukum yang seharusnya (ius constituendum). Kajian hukum positif tidak berhenti pada kajian hukum yang berlaku. Kajian hukum positif selalu menimbulkan pertanyaan tentang hukum yang seharusnya, atau hukum yang diharapkan. ${ }^{6}$

Sementara itu, Utrecht mengutarakan bahwa politik hukum menentukan hukum yang seharusnya. Politik hukum berusaha membuat kaidah-kaidah yang akan menentukan bagaimana seharusnya manusia bertindak. Politik hukum menyelidiki perubahan-perubahan apa yang harus diadakan dalam hukum yang

${ }^{3}$ Bellefroid, JHP, 1952, Inleiding tot de Rechtswetenschap in Nederlands, Dekker \& Van Vegt, Nijmegen Utrecht, hlm. 18, dalam Abdul Latif, Hasbi Ali, Politik Hukum, Sinar Grafika, Jakarta, 2010, hlm. 6 .

${ }^{4}$ Ibid.

${ }^{5}$ Lemaire, WLG, 1955, Het Recht in Indonesia, NV Uitgeveri W. Van Hoeve s'Gravenhage, Bandung, hlm. 2-34, dalam Abdul Latif, Hasbi Ali, Politik Hukum, Sinar Grafika, Jakarta, 2020, hlm. 6.

${ }^{6}$ Ibid., hlm. 7

Politik Hukum Terhadap Pedagang Kaki Lima Dari Perspektif Undang-Undang Dasar Negara Republik Indonesia.

Oleh : Yohanes Suhardin 
sekarang berlaku supaya menjadi sesuai dengan kenyataan sosial (sociale werkelijkheid). ${ }^{7}$

Secara substansial, menurut Satjipto Rahardjo, ${ }^{8}$ politik hukum diarahkan pada hukum yang seharusnya berlaku (ius constituendum). Beberapa pertanyaan mendasar yang dipersoalkan dalam studi politik hukum adalah pertama, tujuan yang hendak dicapai dengan sistem hukum yang ada. Kedua, cara-cara apakah dan yang manakah yang paling baik untuk bisa dipakai mencapai tujuan tersebut. Termasuk di dalamnya menyangkut persoalan pemilihan antara hukum tertulis atau tidak tertulis, antara sentralisasi dan desentralisasi. Ketiga, kapankah waktunya hukum itu perlu diubah dan melalui cara-cara bagaimana perubahan itu sebaiknya dilakukan. Keempat, dapatkah dirumuskan suatu pola yang mapan yang bisa memutuskan proses pemilihan tujuan serta cara-cara untuk mencapai tujuan? Termasuk di dalamnya proses untuk memperbarui hukum secara efisien; dengan perubahan total? Atau dengan perubahan bagian demi bagian?

Lebih lanjut Satjipto Rahardjo, menyatakan bahwa politik hukum ialah aktivitas memilih dan cara yang hendak dipakai untuk mencapai suatu tujuan sosial dan hukum tertentu dalam masyarakat. Logeman menyatakan politik hukum menentukan apa yang berlaku sebagai hukum politik itu sendiri. ${ }^{9}$

Lazimnya politik hukum itu dapat ditemukan dalam konstitusi suatu negara, politik hukum menuntun arah dan sasaran yang ingin dicapai suatu negara yang tergantung pada substansi konstitusi negara. Kata "Konstitusi" yang berarti pembentukan berasal dari kata "Constituer" (Perancis) yang berarti membentuk. Sedangkan istilah "undang-undang dasar" merupakan terjemahan dari Belanda "grondwet". "Grond" berarti dasar, dan "wet" berarti undang-undang. Jadi "Grondwet" sama dengan undang-undang dasar. Namun dalam kepustakaan Belanda dikenal pula dengan istilah "constitutie” yang artinya juga undang-undang dasar. Dalam kepustakaan hukum di Indonesia juga dijumpai istilah "hukum dasar".

Atas dasar pemahaman tersebut, konstitusi disamakan pengertiannya dengan hukum dasar, yang berarti sifatnya bisa tertulis dan tidak tertulis. Sedangkan undang-undang dasar adalah hukum dasar yang tertulis atau yang tertuang dalam

${ }^{7}$ Utrecht, Pengantar dalam Hukum Indonesia, Pradnya Paramita, Jakarta, 1961, hlm. 53.

${ }^{8}$ Satjipto Rahardjo, Ilmu Hukum, Citra Aditya Bakti, Bandung, 2006, hlm. 352.

${ }^{9}$ Ibid.

Politik Hukum Terhadap Pedagang Kaki Lima Dari Perspektif Undang-Undang Dasar Negara Republik Indonesia.

Oleh : Yohanes Suhardin 
suatu nasakah atau dokumen. Sedangkan di samping undang-undang masih ada bagian lain dari hukum yakni yang sifatnya tidak tertulis, dan bisa disebut konvensi atau kebiasaan ketatanegaraan. Konvensi ini merupakan aturan-aturan dasar yang timbul dan terpelihara dalam praktik penyelenggaraan negara walaupun tidak tertulis.

Berikut ini pengertian yang menggambarkan perbedaan antara undangundang dasar dan konstitusi. Bahwa undang-undang dasar adalah suatu kitab atau dokumen yang memuat aturan hukum dan ketentuan-ketetuan hukum yang pokokpokok atau dasar-dasar yang sifatnya tertulis, yang menggambarkan suatu sistem ketatanegaraan. Sedangkan konstitusi adalah dokumen yang memuat aturan-aturan hukum dan ketentuan-ketentuan hukum yang pokok-pokok atau dasar-dasar, yang sifatnya tertulis maupun tidak tertulis, yang menggambarkan tentang sistem ketatanegaraan suatu negara. Sedangkan konstitusi adalah dokumen yang memuat atura-aturan hukum dan ketentuan-ketentuan hukum yang pokok-pokok atau dasardasar yang sifatnya tertulis maupun tidak tertulis, yang menggambarkan tentang sistem ketatanegaraan suatu negara. ${ }^{10}$

Menurut James Bryce, konstitusi adalah suatu kerangka masyarakat politik (negara) dan diorganisir dengan melalui hukum. ${ }^{11}$ Dengan demikian kostitusi merupakan kerangka kehidupan negara yang diatur dengan ketentuan hukum. Pendapat lain menyatakan bahwa konstitusi memiliki 2 (dua) pengertian yaitu pengertian yang luas dan pengertian yang sempit, kecuali di Inggris. ${ }^{12}$

Dalam pengertian yang sempit konstitusi hanya mengacu pada ketentuanketentuan dasar yang tertuang dalam dokumen yang tertulis yaitu undang-undang dasar, sehingga muncul sebutan seperti Konstitusi Amerika Serikat, Konstitusi Prancis, Konstitusi Swiss, dan sebagainya. Sedangkan dalam pengertian yang luas, Konstitusi juga mencakup kebiasaan ketatanegaraan sebagai suatu kaidah yang sifatnya tidak tertulis. Jadi ketika istilah "Konstitusi" disamakan pengertiannya

\footnotetext{
${ }^{10}$ Soehino, Ilmu Negara, Liberty, Yogyakarta, 2005, hlm. 182.

${ }^{11}$ CF. Strong, Konstitusi-Konstitusi Politik Modern, (terjemahan), Nusa Media, Bandung, 2008, hlm. 15

${ }_{12}$ Soemantri Martosuwignjo, Pengantar Perbandingan Antar Hukum Tata Negara, Rajawali, Jakarta,1981,hlm. 62 .

Politik Hukum Terhadap Pedagang Kaki Lima Dari Perspektif Undang-Undang Dasar Negara Republik Indonesia. 
dengan "undang-undang dasar", istilah tersebut hendaknya dipahami dalam pengertian yang sempit.

Undang-undang dasar atau konstitusi negara tidak hanya berfungsi membatasi kekuasaan pemerintah, akan tetapi juga menggambarkan struktur pemerintahan suatu negara. Menurut Savornin Lohman ada 3 (tiga) unsur yang terdapat dalam konstitusi yaitu: ${ }^{13}$

a. Konstitusi dipandang sebagai perwujudan perjanjian masyarakat (kontrak sosial), sehingga menurut pengertian ini, konstitusi-konstitusi yang ada merupakan hasil atau konklusi dari persepakatan masyarakat untuk membina negara dan pemerintah yang akan mengatur mereka.

b. Konstitusi sebagai piagam yang menjamin hak-hak asasi manusia, berarti perlindungan dan jaminan atas hak-hak manusia dan warga negara yang sekaligus penentuan batas-batas hak dan kewajiban baik warganya maupun alatalat pemerintahannya.

c. Konstitusi sebagai forma regimenis, yaitu kerangka bangunan pemerintah.

Pendapat lain dikemukakan oleh Sri Sumantri, yang menyatakan bahwa materi muatan konstitusi dapat dikelompokkan menjadi tiga yaitu pertama, pengaturan tentang perlindungan hak asasi manusia dan warga negara. Kedua, pengaturan tentang susunan ketatanegaraan suatu negara yang mendasar. Ketiga, pembatasan dan pembagian tugas-tugas ketatanegaraan yang juga mendasari. ${ }^{14}$

Ketentuan poin a tersebut itulah yang mendekati politik hukum terhadap pedagang kaki lima, sebab dengan adanya perlindungan terhadap hak asasi manusia dan khususnya warga negara akan tampak keberpihakan dan perhatian terhadap warga negara yang dianggap rentan dari berbagai kebijakan negara. Sebagaimana diketahui salah satu unsur dari hak asasi manusia adalah hak atas hidup dan penghidupan yang layak dan hak atas pekerjaan. Dengan perkataan lain, hak atas hidup dan kehidupan yang layak merupakan hak asasi manusia.

\section{Eksistensi Pedagang Kaki Lima dari Perspektif UUD NRI Tahun 1945}

Secara tersirat eksistensi pedagang kaki lima dari perspektif Undang-Undang Dasar Negara Republik Indonesia Tahun 1945 terdapat dalam Pasal 34UUD NRI Tahun 1945. Bahwasanya UUD NRI tahun 1945 sesungguhnya mempunyai arah yang jelas terhadap pemberdayaan kelompok masyarakat marginal yang dalam

\footnotetext{
13 Ibid.

${ }^{14}$ Ellydar Chaidir, Hukum dan Teori Konstitusi, Kreasi Total Media, Yogyakarta, 2007, hlm. 39.
}

Politik Hukum Terhadap Pedagang Kaki Lima Dari Perspektif Undang-Undang Dasar Negara Republik Indonesia.

Oleh : Yohanes Suhardin 
artikel ini khususnya pedagang kaki lima. Hal tersebut dapat diketahui dari rumusan Pasal 34 ayat (1),(2) dan (3) UUD NRI Tahun 1945 yang menyatakan:

(1) Fakir miskin dan anak-anak yang terlantar dipelihara oleh negara;

(2) Negara mengembangkan sistem jaminan sosial bagi seluruh rakyat dan memberdayakan masyarakat yang lemah dan tidak mampu sesuai dengan martabat kemanusiaan;

(3) Negara bertanggung jawab atas penyediaan fasilitas pelayanan kesehatan dan fasilitas pelayanan yang layak.

Pasal-pasal tersebut selanjutnya dituangkan dalam berbagai peraturan perundang-undangan dengan pedoman kepada stufenbautheorie yang dikemukakan Hans Kalsen. Teori Hans Kalsen yang mendapat banyak perhatian adalah hierarki norma hukum dan rantai validitas yang membentuk piramida hukum (stufenbautheorie). Salah seorang tokoh yang mengembangkan teori tersebut adalah murid Hans Kalsen yaitu Hans Nawiasky. Teori Hans Nawiasky disebut dengan theorie von stufenbau der rechtsordnung. ${ }^{15}$ Susunan norma hukum menurut teori tersebut adalah: (1) norma fundamental negara (staatsfundmentalnorm); (2) aturan dasar negara (Staatsgrundgesetz); (3) undang-undang formal (formelagesetz); (4) peraturan pelaksanaan dan peraturan otonom (verordnung en autonome satzung). Staatsfundamentalnorm adalah norma yang merupakan dasar bagi pembentukan konstitusi atau undang-undang dasar (Staatsverfassung) dari suatu negara. Posisi hukum dari suatu staatsfundmentalnorm adalah sebagai syarat bagi pelakunya suatu konstitusi. Staatsfundmentalnorm ada terlebih dahulu dari konstitusi suatu negara. Menurut Hans Nawiasky, norma tertinggi yang oleh Hans Kelsen disebut sebagai norma dasar (basic norm) dalam suatu negara sebaiknya tidak disebut sebagai staatsgrundnorm melainkan staatsfundmentalnorm, atau norma fundamental negara. Grundnorm pada dasarnya tidak berubah-ubah, sedangkan norma tertinggi berubah misalnya dengan cara kudeta atau revolusi.

Berdasarkan teori Nawiasky tersebut, A. Hamid S. Attamimi membandingkannya dengan teori Hans Kelsen dan menerapkannya pada struktur tata hukum di Indonesia. Attamimi menunjukan struktur hierarki tata hukum

${ }^{15}$ Ibid.

Politik Hukum Terhadap Pedagang Kaki Lima Dari Perspektif Undang-Undang Dasar Negara Republik Indonesia.

Oleh : Yohanes Suhardin 
Indonesia dengan menggunakan teori Nawiasky. Berdasarkan teori tersebut, struktur dan tata hukum di Indonesia adalah: (1) Staatsfundamentalnorm: Pancasila (Pembukaan UUD 1945); (2) staatsgrundgestz: Batang Tubuh UUD 1945, Tap MPR, dan Konvensi ketatanegaraan; (3) formell gesetz: undang-undang; (4) verordnung en autonome satzung: secara hierarki mulai dari peraturan pemerintah hingga Keputusan Bupati atau Walikota.

\section{Politik Hukum terhadap PKL dari Perspektif UUD NRI Tahun 1945}

Pada umumnya tujuan didirikannya setiap negara di muka bumi adalah dalam rangka mewujudkan kebahagiaan bagi rakyatnya. Meskipun banyak istilah yang digunakan oleh masing-masing negara yang biasanya tergantung dari ideologi negara tersebut, namun yang pasti tujuan akhirnya membuat rakyatnya bahagia. Ada negara yang menggunakan istilah kebaikan umum atau disebut juga bonum commune, ada juga yang menggunakan istilah kepentingan umum atau kemakmuran rakyat. Umumnya banyak yang menggunakan istilah kesejahteraan umum termasuk negara kita Republik Indonesia.

Terkait dengan hal tersebut, Roger H. Soltau menyatakan bahwa tujuan negara adalah memungkinkan rakyatnya "berkembang serta menyelenggarakan daya ciptanya sebebas mungkin" (the freest possible development and creative selfexpression of its member). Sedangkan menurut Harold J. Laski tujuan negara adalah "menciptakan keadaan di mana rakyatnya dapat mencapai keinginan-keinginan secara maksimal", (creation of those conditions under which the members of the state may attain the maximum satisfication of their desires $).{ }^{16}$

Namun setiap negara, apapun ideologi yang dianutnya menyelenggarakan fungsi minimum yang mutlak fifatnya, yaitu: ${ }^{17}$ pertama, melaksanakan penertiban (law and order). Untuk memncapai tujuan bersama dan mencegah bentrokanbentrokan dalam masyarakat, negara harus melaksanakan penertiban. Dapat dikatakan bahwa negara bertindak sebagai stabilisator. Kedua, mengusahakan kesejahteraan dan kemakmuran rakyatnya. Fungsi ini dianggap sangat penting, terutama bagi negara-negara baru di mana tingkat kesejahteraan masyarakat masih sangat membutuhkan perhatian dari pemerintah. Ketiga, pertahanan. Fungsi ini

\footnotetext{
${ }^{16}$ Miriam Budiardjo, Dasar-dasar Ilmu Politik, Gramedia Pustaka Utama, Jakarta, 2010, hlm. 54.

${ }^{17}$ Ibid.
}

Politik Hukum Terhadap Pedagang Kaki Lima Dari Perspektif Undang-Undang Dasar Negara Republik Indonesia.

Oleh : Yohanes Suhardin 
mempertahankan negara dari kemungkinan serangan dari luar, sehingga negara harus dilengkapi dengan alat-alat pertahanan.

d. Menegakkan keadilan. Untuk mewujudkan keadilan negara memiliki badanbadan peradilan.

Sementara itu menurut Charles E. Meriam, fungsi yang harus dijalankan oleh negara meliputi fungsi keamanan ekstern, fungsi ketertiban intern, fungsi keadilan, fungsi kesejahteraan umum, dan fungsi kebebasan. ${ }^{18}$ Negara Kesatuan Republik Indonesia (NKRI) menjelang kemerdekaannya oleh para pendiri negara (the founding fathers) telah sepakat menentukan tujuan negara. Adapun tujuan Negara Republik Indonesia sesuai dengan Alinea IV Pembukaan UUD NRI Tahun 1945, adalah pertama, melindungi segenap bangsa Indonesia dan seluruh tumpah darah Indonesia; kedua, memajukan kesejahteraan umum; ketiga, mencerdaskan kehidupan bangsa; keempat, ikut melaksanakan ketertiban dunia yang berdasarkan kemerdekaan, perdamaian abadi, dan keadilan sosial.

Tujuan Negara Republik Indonesia tersebut hendak diwujudkan di atas landasan Ketuhanan Yang Maha Esa; Kemanusiaan Yang Adil dan Beradab; Persatuan Indonesia; Kerakyatan yang Dipimpin oleh Hikmat kebijaksanaan dalam Permusyawaratan/Perwakilan; serta keadilan sosial bagi seluruh Rakyat Indonesia. Memajukan kesejahteraan umum sebagaimana ditegaskan di dalam Alinea keempat Pembukaan UUD NRI Tahun 1945, sesungguhnya adalah jaminan akan adanya kepastian hukum keberpihakan negara terhadap masyarakat yang dikategorikan rentan antara lain para pedagang kaki lima. Sehubungan dengan itu, Franz Magnis Suseno menyatakan bahwa apabila bertolak dari tugas negara untuk mendukung dan melengkapkan usaha masyarakat untuk membangun suatu kehidupan yang sejahtera, di mana masyarakat dapat hidup dengan sebaik dan seadil mungkin, maka tujuan Negara adalah penyelenggaraan kesejahteraan umum. ${ }^{19}$

Apa yang dimaksud dengan kesejahteraan umum? Kesejahteraan umum tidak identic dengan jumlah kesejahteraan semua anggota masyarakat. Kesejahteraan umum sekaligus kurang dan lebih dari jumlah semua kesejahteraan

18 Direktorat Pembelajaran dan Kemahasiswaan Direktorat Jenderal Pendidikan Tinggi Departemen Pendidikan Nasional Kementerian Pendidikan dan Kebudayaan Republik Indonesia, Mata Kuliah Pendidikan Kewarganegaraan, Jakarta, 2013, hlm. 37.

${ }^{19}$ Franz Magnis Suseno, Etika Politik.....

Politik Hukum Terhadap Pedagang Kaki Lima Dari Perspektif Undang-Undang Dasar Negara Republik Indonesia. 
individual dalam masyarakat. Kurang karena negara selalu hanya dapat menyelenggarakan kondisi-kondisi kesejahteraan bagi warga-warganya, tetapi tidak dapat memastikan bahwa mereka semua memang sejahtera. Kesejahteraan individual tidak hanya tergantung darri apa yang disediakan oleh masyarakat dan negara, tetapi juga dari individu yang bersanhgkutan. Lebih karena masyarakat sendiri adalah lebih dari penjumlahan semua individu yang menjadi anggotaanggotanya. Kesejahteraan umum dapat dirumuskan sebagai "keseluruhan prasyarat-prasyarat sosial yang memungkinkan atau mempermudah manusia untuk mengembangkan semua nilainya, atau sebaagai jumlah semua kondisi kehidupan social yang doperlukan agar masing-masing individu, keluarga-keluarga, dan kelompok-kelompok masyarakat dapat mencapai keutuhan atau perkembangan mereka dengan lebih utuh dan cepat.

Menurut Franz Magnis Suseno, kesejahteraan umum terdiri atas syaratsyarat yang harus dipenuhi agar masyarakat sendiri dapat merasa sejahtera. Kapan seseorang merasa sejahtera? Jawabannya harus dirumuskan baik secara negatif maupun secara positif. Secara negatif, manusia disebut sejahtera apabila ia bebas dari perasaan lapar dan dari kemiskinan, dari kecemasan akan hari esok, bebas dari perasaan takut, dari penindasan, apabila ia tidak merasa dierlakuan dengan tiak adil. $^{20}$

Lebih lanjut dikatakan, secara positif manusia dapat disebut sejahtera apabila ia merasa aman, tenteram, selamat, apabila ia dapat hidup sesuai sesuai dengan cita-cita dan nilai-nilainya sendiri, apabila ia merasa bebas untuk mewujudkan kehidupan individual dan sosialnya sesuai dengan aspirasi-aspirasi serta dengan kemungkinan-kemungkinan yang tersedia baginya. Apabila kemampuan dan kreativitasnya, meskipun terbatas, bisa dikembangkannya, apabila ia merasa tenang dan bebas. ${ }^{21}$

Sebagaimana telah dikatakan di muka, bahwa istilah yang baku di dalam UUD NRI Tahun 1945, khususnya pada aline keempat adalah "kesejahteraan umum". Lengkapnya adalah "memajukan kesejahteraan umum”. Jika alat ukurnya adalah apa yang dikatakan Franz Magnis Suseno di atas, maka yang terjadi adalah sebatas

\footnotetext{
${ }^{20}$ Franz Magnis Suseno, Etika Politik - Prinsip Moral Dasar Kenegaraan Modern, Gramedia Pustaka Utama, Jakarta, 2019, hlm. 402.

${ }^{21}$ Ibid.

Politik Hukum Terhadap Pedagang Kaki Lima Dari Perspektif Undang-Undang Dasar Negara Republik Indonesia. 
pada politik hukum saja. Memang akhir-akhir ini terutama dalam lima tahun terakhir ini parameter tersebut di atas mulai dirumuskan secara detail melalui peraturan perundang-undangan maupun kebijakan pemerintah lainnya.

Secara das sollen politik hukum terhadap pedagang kaki lima dari perspektif Undang-Undang Dasar Negara Republik Indonesia telah diatur secara tersirat mulai dari Pembukaan UUD NRI Tahun 1945 sampai dengan Batang Tubuh UUD NRI Tahun 1945. Pembukaan UUD NRI Tahun 1945 meskipun tidak dengan tegas menyatakan pedagang kaki lima, namun dari Alinea Keempat Pembukaan UUD NRI Tahun 1945 tampak bahwa secara politik hukum niat dan keberpihakan kepada pedagang kaki lima sudah cukup baik mengaturnya.

Selanjutnya di dalam Batang Tubuh UUD NRI Tahun 1945 politik hukum terhadap masyarakat marginal yang antara lain adalah pedagang kaki lima yaitu di dalam Pasal 27 ayat (2), 33 dan 34 UUD NRI Ttahun 1945. Pasal 27 ayat (2) UUD NRI Tahun 1945 menyatakan: "tiap-tiap warga negara berhak atas pekerjaan dan penghidupan yang layak bagi kemanusiaan”. Artinya bahwa arah kebijakan hukum terhadap pedagang kaki lima, memang sudah diatur sedemikian baik.

Pasal berikutnya dalam UUD NRI Tahun 1945 adalah: Pasal 33 UUD NRI Tahun 1945 menyatakan: (1) perekonomian disusun sebagai usaha bersama berdasar atas azas kekeluargaan; (2) cabang-cabang produksi yang penting bagi negara dan yang menguasai hajat hidup orang banyak dikuasai negara; (3) Bumi, air dan kekayaan alam yang terkandung di dalamnya dikuasai oleh negara dan dipergunakan sebesar-besar untuk kemakmuran rakyat; (4) perekonomian nasional diselenggarakan berdasar atas demokrasi ekonomi dengan prinsip kebersamaan, efisiensi berkeadilan, berkelanjutan, berwawasan lingkungan, kemandirian, serta dengan menjaga keseimbangan kemajuan dan kesatuan ekonomi nasional; dan (5) ketentuan lebih lanjut mengenai pelaksanaan pasal ini diatur dalam undang-undang.

Selanjutnya di dalam Pasal 34 UUD NRI Tahun 1945 merupakan pengaturan yang lebih dekat politik hukum terhadap pedagang kaki lima. Usaha pemerintah untuk mencapai kesejahteraan bersama dilakukan dengan cara pertama, melindungi orang-orang terhadap risiko bekerjanya industri modern, seperti kecelakaan perburuhan; kedua, menjamin penghasilan minimum, juga karena sakit, kehilangan pekerjaan dan masa tua; ketiga, menyediakan sarana yang dibutuhkan 
oleh setiap orang agar dapat berfungsi dengan baik dalam masyarakat, seperti perumahan, pendidikan dan kesehatan; ketiga, memajukan kesejahteraan individu, seperti penyaluran aspirasi politik, kebudayaan, olahraga dan sebagainya.

Pada umumnya tujuan negara: (a) memperluas kekuasaan; (b) menyelenggarakan ketertiban umum; dan (c) mencapai kesejahteraan umum. Tujuan negara menurut Plato, memajukan kesusilaan manusia, sebagai perseorangan (individu) dan sebagai makhluk sosial. Tujuan negara menurut Roger H. Soltau, memungkinkan rakyatnya berkembang serta menyelenggarakan daya ciptanya sebebas mungkin (the freest possible development and creative selexpression of its members). Tujuan negara Republik Indonesia, memajukan kesejahteraan umum, mencerdaskan kehidupan bangsa, dan ikut melaksanakan ketertiban dunia yang berdasarkan kemerdekaan, perdamaian abadi dan keadilan sosial. Unsur rakyat sangat penting dalam sebuah negara, karena secara konkret rakyatlah yang memiliki kepentingan agar negara itu dapat berjalan dengan baik.

Ciri khas negara kesejahteraan bahwa yang diselenggarakan bukan harganya fasilitas-fasilitas yang dapat dipergunakan oleh masyarakat, melainkan negara wajib menyelenggarakan berbagai pelayanan termasuk pelayanan kesehatan, pendidikan, pembangunan jalan dan pengadaan sarana lalu lintas, fasilitas pos dan telekomunikasi, radio dan televisi, pelbagai pelayanan sosial, menciptakan atau memberikan bantuan bagi lembaga-lembaga kultural; dan terutama di negaranegara modern, pelbagai cara untuk mengembangkan kemampuan ekonomis bangsa dengan tujuan agar semua anggota masyarakat, minimal dapat hidup bebas dari kemiskinan dan ketergantungan ekonomi yang berlebihan. Lebih lanjut ditegaskan kembali bahwa "dianutnya prinsip demokrasi ekonomi dan paham ekonomi pasar sosial dapat kita lihat pada ketentuan Bab XIV UUD 1945. Ketentuan konstitusi tersebut harus mendasari perumusan berbagai ketentuan mengenai perekonomian dan kesejahteraan sosial di Indonesia.

Manusia memerlukan lebih dari sekadar kebutuhan dasar seperti pangan, pakaian dan perumahan agar bisa menjalani kehidupan bermasyarakat sehari-hari. Seberapa banyak yang diperlukan tentu tidak bisa ditetapkan secara umum, hal itu bergantung pada kondisi kultural dalam masyarakatnya. Hal yang terpenting adalah setiap orang bisa, tanpa rasa malu, dan terhalang, berpartisipasi sepenuhnya dalam 
interaksi sehari-hari dengan orang lain. Ini berarti, mereka bisa menikmati kebutuhan-kebutuhan dasar secara terhormat. Tak seorang pun diperbolehkan hidup dalam kondisi sedemikian rupa, sehingga cara mereka memenuhi kesejahteraannya, dengan merendahkan diri atau mengabaikan kebebasan dasarnya, dengan memintaminta, melacur atau memperbudak diri, hanya untuk mendapatkan kebutuhan mereka.

Dalam istilah murni material, "Kelayakan standard hidup" mesti dipahami sebagai cara mempertahankan tingkat kehidupan di atas garis kemiskinan. Realisasi hak-hak asasi manusia jelas menuntut penghapusan kemiskinan di seluruh dunia, seperti digambarkan "Four freedom addres", pada 1941, yang kemudian menjadi salah satu inspirasi dari Deklarasi Universal Hak Asasi Manusia serta ketentuanketentuan hak asasi manusia lainnya.

Hak atas kesejahteraan (jauh dari kemiskinan) tidak lain dari asas keadilan sosial bagi seluruh rakyat Indonesia. Hak-hak dasar persamaan dan kebebasan (Thomas Jefferson) adalah teori yang menyatakan bahwa semua manusia yang dilahirkan sama dan merdeka. Manusia dianugerahi beberapa hak yang tidak terpisah-pisah, di antaranya hak kebebasan dan tuntutan kesenangan. Teori ini banyak dipengaruhi oleh John Locke sekaligus menandai perkembangan HAM kemudian.

Empat hak kebebasan manusia (the four freedoms) di Amerika Serikat pada 6 Januari 1941, yang diproklamirkan oleh Presiden Theodore Roosevelt. Keempat hak itu adalah (1) hak kebebasan berbicara dan menyatakan pendapat; (2) hak kebebasan memeluk agama dan beribadah sesuai dengan ajaran agama yang dipeluknya; (3) hak bebas dari kemiskinan; dan (4) hak bebas dari rasa takut.

Menurut Muladi, dalam kerangka demokrasi, indikator pemerintahan yang terbuka, bertanggung jawab, responsif adalah pertama, adanya prinsip keterbukaan informasi; dalam hal ini di samping perhatian terhadap HAM berupa "kebebasan berekspresi", maka dalam pembatasannya jelas dibutuhkan apa yang dinamakan semacam "The Freedom of Information Act" (FOIA). Kedua, adanya jaminan ketaatan penguasa terhadap prinsip kedaulatan hukum atas dasar prinsip "equality before the law". Dalam hal ini harus dicegah terjadinya penegakan hukum yang selektif dan mengandung hak-hak istimewa (privilege). Ketiga, ditegakkannya asas 
kekuasaan kehakiman yang merdeka dan bertanggungjawab. Merdeka berarti bahwa dalam melaksanakan judicial power, hakim harus bebas dari pengaruh eksternal, seperti eksekutif, legislatif, kepentingan pribadi, kelompok, golongan, pengaruh pers, pengaruh $\mathrm{KKN}$; selain juga pengaruh internal dari lingkungan peradilan yang lebih tinggi. Keempat, adanya jaminan yang luas bagi warga negara untuk memperoleh keadilan (access to justice) apabila terlanjur menjadi korban akibat malpraktik dalam penegakan hukum, baik berupa "mal administration" maupun "miscarriage of justice" yang dilakukan oleh pemerintah maupun lembaga-lembaga publik. Di samping melalui lembaga-lembaga pengadilan, lembaga semacam "ombudsman" dan Komnas HAM menjadi sangat strategis keberadaannya. Kelima, diperlukan perundang-undangan yang demokratis dan aspiratif; melalui koridor akademis, birokratis, sosial dan politik, akan terjaring secara proporsional aspirasi suprastruktur, infrastruktur dan aspirasi kepakaran. Keenam, adanya sarana dan prasarana yang memadai. Sarana dan prasarana ini mencakup aspek material, finansial, dan kelembagaan yang betul-betul memadai. ${ }^{22}$

Adapun yang disebut warga negara adalah anggota komunitas suatu negara yang setia dan mematuhi semua undang-undang yang berlaku di negara tersebut. Sebagai konsekuensi atas kesetiaan dan kepatuhan itu, warga negara diharuskan membayar pajak, fiskal, dan kewajiban-kewajiban lain yang ditetapkan oleh negara melalui undang-undang yang ditetapkan oleh badan legislatif yang mewakili aspirasi negara. ${ }^{23}$ Sebagai imbalan dari kesetiaan dan kepatuhan itu, negara berkewajiban menjamin dan melindungi hak-hak setiap warga negara. Negara yang abai atau gagal melindungi hak-hak warganya, bisa dituntut di muka hukum bahkan bisa di depan Mahkamah Internasional dengan landasan, pertama, Deklarasi Universal tentang Hak-Hak Asasi Manusia yang disetujui dan diumumkan oleh Resolusi Majelis Umum PBB, 10 Desember 1948. Kedua, Kovenan Internasional tentang Hak-Hak Sipil dan Politik. Ketiga, Kovenan Internasional tentang Hak-Hak Ekonomi, Sosial, dan Budaya. Sebagai negara demokrasi, Indonesia sudah memasukkan semua hak-hak warga negara ke dalam UUD 1945, dan dalam

\footnotetext{
${ }^{22}$ Muladi, Demokratisasi Hak Asasi Manusia dan Reformasi Hukum di Indonesia, Cet. 2, The Habibie Center, Jakarta, 2002, hlm. 6.

${ }^{23}$ Jeffrie Geovanie, Membela Akal Sehat: Upaya Menyelaraskan Politik, Agama dan Budaya dengan Akal Sehat, Gramedia Pustaka Utama, Jakarta, hlm. 60.
}

Politik Hukum Terhadap Pedagang Kaki Lima Dari Perspektif Undang-Undang Dasar Negara Republik Indonesia. 
Undang-Undang bidang politik, ekonomi, sosial dan budaya. Namun, masih tingginya angka pengangguran, tingkat kemiskinan, gelandangan, dan tingkat kebodohan (bahkan buta huruf), merupakan bukti ketidakmampuan pemerintah memenuhi hak-hak warga negara bidang ekonomi, sosial, dan budaya.

Di sini dipertegas bahwa negara Indonesia tetap berkomitmen dengan bentuk negara kesejahteraan (welfare state) sebagaimana terbukti dengan adanya amandemen Pasal 33 dengan menambah 2 ayat. Dengan ditambahnya 2 ayat tersebut, sistem kesejahteraan khususnya dalam bidang ekonomi menerima sisi positif dari sistem liberalis dan sosialis, tetapi tetap menolak pandangan fundamentalisme pasar (market fundamentalism). Paham negara kesejahteraan (welfare state) ternyata dipertegas dalam tambahan pasal-pasal sosial-ekonomi, yaitu dalam Pasal 34 ayat (2) dan ayat (3). Sementara itu, Pasal 33 ayat (3) merupakan penegasan negara nesejahteraan dengan mengambil istilah yang dipakai Giddens sebagai "negara investasi sosial” (social investment state). ${ }^{24}$

Franz Magnis Suseno, kalau hak-hak negatif menghalau campur tangan negara dalam urusan pribadi manusia, di sini terdapat hal-hal yang berhak dituntut oleh manusia dan masyarakat dari negara. Maka, disebut juga hak-hak positif karena menuntut tindakan positif. Ada pelayanan-pelayanan yang wajib diberikan oleh negara kepada masyarakat. Hak utama adalah ha katas perlindungan hukum. Di sini termasuk hak atas perlakuan yang sama di depan hukum, hak agar suatu pelanggaram terhadap hak-hak yang dmiliki tidak dibiarkan. Dengan demikian, hak atas perlindungan hukum termasuk hak asasi yang paling tua.

Dalam kategori Conhran dan Malone, sebuah kebijakan dimaknai sebagai publik (kebijakan publik) bila kebijakan tersebut berkaitan dengan keputusan dan tindakan pemerintah yang didesain untuk menyelamatkan persoalan rakyat (public concern). Tetapi yang paling urgen di sini adalah sepanjang urusan itu berkaitan dengan tujuan keadilan sosial sebagai filsafat politik berdirinya negara, maka dengan cepat hal itu direspon sebagai hajat hidup publik.

Dalam tradisi klasik filsafat politik, tugas negara adalah mempertahankan keselarasan sosial atau untuk meminjam istilah Thomas Aquinas, untuk menyelenggarakan bonum commune atau kesejahteraan umum. Akan tetapi

\footnotetext{
${ }^{24}$ Ibid.
}

Politik Hukum Terhadap Pedagang Kaki Lima Dari Perspektif Undang-Undang Dasar Negara Republik Indonesia. 
perkembangan umat manusia terutama di bidang sosial ekonomi, memaksa negara untuk memperluas paham tanggung jawabnya: tidak cukuplah sekadar mempertahankan keselarasan sosial atau menyelenggarakan kesejahteraan umum. Masyarakat juga harus dikembangkan atau dibangun. Dengan perkataan lain, zaman sekarang setiap negara harus mengusahakan pembangunan nasional.

Pada konsep negara kesejahteraan (welvaartsstaats), negara mengabdi sepenuhnya kepada masyarakat. Dalam negara kesejahteraan, negara adalah alat satu-satunya untuk menyelenggarakan kesejahteraan rakyat. Negara berperan aktif dalam menyelenggarakan kesejahteraan warganya untuk kepentingan seluruh rakyat dan negara. Jadi pada tipe negara kesejahteraan, tugas negara adalah sematamata menyelenggarakan kesejahteraan rakyat semaksimal mungkin. ${ }^{25}$

Jimly Asshiddiqie ${ }^{26}$ merumuskan kembali adanya dua belas prinsip pokok negara hukum (rechtsstaat) yang berlaku di zaman sekarang di Indonesia sebagaimana dicantumkan dengan tegas dalam Pasal 1 Ayat (3) yang berbunyi: "negara Indonesia adalah negara hukum". Cita negara hukum tersebut mengandung 12 prinsip berikut, pertama, supremasi hukum (supremacy of law); kedua, persamaan dalam hukum (equality before the law); ketiga, Asas legalitas (due Process of law); keempat, pembatasan kekuasaan; kelima, organ-organ eksekutif independen; keenam, peradilan bebas dan tidak memihak; ketujuh, Peradilan Tata Usaha Negara; kedelapan, peradilan Tata Negara (Constitutional Court); kesembilan, perlindungan Hak Asasi Manusia; kesepuluh, bersifat demokratis (Democratische Rechtsstaat); kesebelas, berfungsi sebagai sarana mewujudkan tujuan bernegara (welfare Rechsstaat); keduabelas, transparansi dan kontrol sosial.

Selanjutnya Jimly Asshiddiqie ${ }^{27}$ menegaskan bahwa hukum berfungsi sebagai sarana mewujudkan tujuan bernegara (welfare rechtsstaat) artinya hukum adalah sarana untuk mencapai tujuan yang diidealkan bersama. Cita-cita hukum itu sendiri, baik yang dilembagakan melalui gagasan negara demokrasi (democracy) maupun yang diwujudkan melalui gagasan negara hukum (nomokrasi/nomocracy)

\footnotetext{
${ }^{25}$ Ellydar Chaidir, Negara Hukum, Demokrasi dan Konstelasi Ketatanegaraan Indonesia, Total Media, Yogyakarta, 2011, hlm. 31

${ }^{26}$ Jimly Asshiddiqie, "Cita Negara Hukum Indonesia Kontemporer”, Orasi Ilmiah pada Wisuda Sarjana Hukum Fakultas Hukum Universitas Sriwijaya Palembang, 23 Maret 2004, Simbur Jaya No. 25 Tahun IX Mei 2004 ISSN No. 14110-0614.

${ }^{27}$ Ibid.
}

Politik Hukum Terhadap Pedagang Kaki Lima Dari Perspektif Undang-Undang Dasar Negara Republik Indonesia.

Oleh : Yohanes Suhardin 
dimaksudkan untuk meningkatkan kesejahteraan umum. Bahkan sebagaimana citacita nasional Indonesia yang dirumuskan dalam Pembukaan UUD 1945, tujuan bangsa Indonesia bernegara adalah dalam rangka melindungi segenap bangsa Indonesia dan seluruh tumpah darah Indonesia, memajukan kesejahteraan umum, mencerdaskan kehidupan bangsa, dan ikut melaksanakan ketertiban dunia berdasarkan kemerdekaan, perdamaian abadi dan keadilan sosial. Negara hukum berfungsi sebagai sarana untuk mewujudkan dan mencapai keempat tujuan negara Indonesia tersebut. Dengan demikian, pembangunan negara Indonesia tidak akan terjebak menjadi sekedar "rule driven" melainkan tetap "mission driven", tetapi "mission driven" yang tetap didasarkan atas aturan.

Selanjutnya Franz Magnis Suseno ${ }^{28}$ menyatakan bahwa paham hak asasi positif berdasarkan anggapan bahwa negara bukan tujuan pada dirinya sendiri, melainkan merupakan lembaga yang diciptakan dan dipelihara oleh masyarakat untuk memberikan pelayanan-pelayanan tertentu. Maka, masyarakat dengan sendirinya berhak atas pelayanan itu dan negara wajib untuk memberikannya. Menurut paham itu, pelayanan negara terhadap masyarakat bukanlah suatu anugerah yang harus dimohonkan oleh masyarakat, melainkan masyarakat berhak untuk menuntutnya. Negara yang memberi pelayanan itu hanya memenuhi kewajibannya saja. Oleh karena itu, pelayanan keperluan masyarakat oleh negara pada prinsipnya tidak boleh ditarik pembayarannya. Salah satu implikasi hak atas perlindungan hukum dan pelayanan oleh negara pada umumnya adalah bahwa tidak boleh ada anggota masyarakat yang tidak mendapat pelayanan itu hanya karena ia terlalu miskin untuk membayar biayanya.

Berdasarkan pendapat Jimly Asshidiqie dan Franz Magnis Suseno, ada kesepahaman bahwa konsep negara kesejahteraan sejatinya tampak juga dalam UUD NRI Tahun khususnya terdapat dalam Pasal 34 UUD NRI Tahun 1945 yang didukung oleh Pasal 33 UUD NRI Tahun 1945. Hal tersebut berarti secara politik hukum eksistensi pedagang kaki lima telah tersirat di dalam UUD NRI Tahun 1945 terutama dalam Pasal 34 ayat (2). Sampai dengan tahun 2011 jumlah pedagang kaki lima mencapai 20 juta di Indonesia dan pasti sudah bertambah saat ini, maka implementasi politik hukum terhadap pedagang kaki lima dikonkritkan lagi dengan

\footnotetext{
${ }^{28}$ Frans Magnis Suseno,..Etika Politik,...Op. Cit., hlm. 177.
} 
adanya Undang-Undang tersendiri yang mengatur secara khusus pedagang kaki lima, sehingga penataan terhadap pedagang kaki lima bisa lebih baik lagi.

\section{KESIMPULAN}

Politik hukum terhadap pedagang kaki lima dari perspektif Undang-Undang Dasar Negara Republik Indonesia secara tersirat tampak dalam ketentuan Pasal 34 UUD NRI 1945, khususnya ayat (2) yang menyatakan negara mengembangkan sistem jaminan sosial bagi seluruh rakyat dan memberdayakan masyarakat yang lemah dan tidak mampu sesuai dengan martabat kemanusiaan (das sollen). Namun persoalan kemauan politik (political will) pemerintah terhadap pemberdayaan pedagang kali lima (das sein) belum konsisten dengan semangat dari UUD NRI Tahun 1945, sehingga sulit terwujudnya kesejahteraan masyarakat, khususnya pedagang kaki lima.

\section{E. REKOMENDASI}

Dalam rangka terwujudnya kesejahteraan umum sebagaimana diinginkan oleh UUD NRI Tahun 1945, maka harus dilakukan pendataan yang akurat terhadap jumlah pedagang kaki lima di Indonesia. Setelah itu, segera diterbitkan undangundang khususnya yang mengatur tentang Pedagang Kaki Lima yang jumlahnya saat ini diperkirakan 25 juta orang.

\section{DAFTAR PUSTAKA}

Chaidir, Ellydar, 2007, Hukum dan Teori Konstitusi, Kreasis Total Media, Yogyakarta.

Huijbers, Theo, 1999, Filsafat Hukum, Kanisius, Yogyakarta.

Lubis M. Solly, 1982, Asas-asas Hukum Tata Negara, Bandung.

Mahfud MD, Moh, 2006, Membangun Politik Hukum, Menegaskan Konstitusi, LP3ES Jakarta.

------, 2010, Politik Hukum di Indonesia, Rajawali Pers, Jakarta

Martosuwignjo, Soemantri, 1981, Pengantar Perbandingan Antar Hukum Tata Negara, Rajawali, Jakarta.

Nasution, Adnan Buyung - A. Patra M. Zen (Penyunting), 2006, Instrumen internasional Pokok Asasi Manusia, Yayasan Obor Indonesia - Yayasan Lembaga Bantuan Hukum Indonesia -Kelompok Ake Arief, Jakarta

Rahardjo, Satjipto, 2006, Ilmu Hukum, Citra aditya Bakti, Bandung.

Soedarto, 1986, Hukum dan Hukum Pidana, Alumni, Bandung.

Soehino, 2005, Ilmu Negara, Liberty, Yogyakarta.

Strong, CF, 2008, Konstitusi-konstitusi Politik Modern, (Terjemahan), Nusa Media Bandung. 
Suhardin, Yohanes, Rudy Haposan Siahaan, 2015, Pengaruh Budaya Sistem Hukum Asing Terhadap Negara Hukum Kesejahteraan Indonesia, PT. Sofmedia, Jakarta.

Suseno, Franz Magnis, 2019, Etika Politik - Prinsip Moral Dasar Kenegaraan Modern, Penerbit PT. Gramedia Pustaka Utama, Jakarta.

Jimly Asshiddiqie, "Cita Negara Hukum Indonesia Kontemporer", Orasi Ilmiah pada Wisuda Sarjana Hukum Fakultas Hukum Universitas Sriwijaya Palembang, 23 Maret 2004, Simbur Jaya No. 25 Tahun IX Mei 2004 ISSN No. 14110-0614.

Radhie, Teuku Mohammad, "Pembaruan dan Politik Hukum dalam rangka Pembangunan Nasional", artikel dalam Majalah Prisma Nomor 6 Tahun II Desember 1973.

Suharto, Edi, Kapitalisme dan Negara Kesejahteraan, dalam http://www.policy.hu/suharto, diakses, 28 Agustus 2016, jam 23.26 WIB. 